\title{
Ecophysiology and stress response of marine and brackish water Gammarus species (Crustacea, Amphipoda) to changes in salinity and exposure to cadmium and diesel-oil
}

\author{
Michael Tedengren, Marie Arnér, Nils Kautsky \\ Askö Laboratory, Institute of Marine Ecology and Department of Zoology, University of Stockholm, S-106 91 Stockholm, \\ Sweden
}

\begin{abstract}
There is a current debate whether organisms living in estuaries should be more sensitive to pollution than their marine relatives, but few comparative studies have been made. Amphpods of the genus Gammarus are generally euryhaline and 5 species are common to the brackish Baltic Sea ( $7 \% \mathrm{~S}$ ) and the North Sea $(30 \%$ S). Laboratory measurements on the metabolism of $G$ duebeni and $G$. oceanicus from the 2 areas showed that respiration and oxygen:nitrogen ratios of $G$. duebeni were generally less affected by salinity changes and/or additions of diesel oil and cadmium than $G$. oceanicus. We interpret this as a higher tolerance of $G$. duebeni to pollutants and salinity changes, probably coupled to this species being physiologically broad-niched and having evolved in, and being adapted to, physically more variable environments. The Baltic populations of $G$. duebeni and $G$. oceanicus were generally more sensitive to salinity changes and treatments with diesel-oll than their North Sea conspecifics. The higher sensitivity to pollutants of the Baltic populations may be due to a number of factors such as changes in the characteristics of toxic substances (metals) with salinity, the higher relative ionic concentration of a given amount of poisonous substance in the low-saline Baltic Sea than in the North Sea, and direct interactions of toxicants with membrane permeability and osmoregulatory mechanisms, which are already under strain at low salinities.
\end{abstract}

\section{INTRODUCTION}

The widely distributed amphipod genus Gammarus inhabits marine, brackish- and fresh-water habitats. To cope with a range of environmental conditions in their particular aquatic habitats, species diversity and niche variability are high (e.g. Kolding 1985), yielding a promising material for experimental investigations on adaptation and underlying physiological mechanisms.

Considerable experimental and theoretical work has been done on the physiological characteristics of Gammarus spp. (Kinne 1952, 1959, 1964, 1971, Bulnheim 1972, 1979, Dorgelo 1973, Sutcliffe 1984) as well as on life cycle characteristics, population dynamics and genetics of the genus (Fenchel \& Kolding 1979, Kolding \& Fenchel 1979, Bulnheim \& Scholl 1981, Kolding 1981, 1986, Kolding \& Fenchel 1981). In the Baltic Sea 5 species of Gammarus are found that also inhabit the North Sea. These are $G$. oceanicus Segerstråle, $G$. locusta (L.), G. salinus Spooner, G. Zaddachi Sexton and $G$. duebeni Liljeborg.

Although many studies have been performed on the effects of a variety of toxicants on marine organisms, there are relatively few on estuarine animals (McLusky et al. 1986), and estimation of the effects of a certain pollutant on estuarine ecosystems have often been derived from experiments with marine organisms that have been subjected to combinations of lowered salinity and toxicants, and generally not from comparative studies between estuarine organisms and their marine conspecifics in their respective environments.

Thus, the general sensitivity of the brackish Baltic Sea and the marine North Sea has been much debated (Gray 1981, Landner et al. 1982), some regarding the Baltic Sea as more sensitive and some considering the North Sea as more vulnerable to pollution. Those regarding the Baltic as more sensitive base their opinion on the concept that organisms living near to the 
limit of their tolerance range (e.g. salinity) should be more susceptible to any additional stress (e.g. McLusky et al. 1986). This theory has been experimentally validated for a number of different species and for toxicants such as cadmium (Theede 1980, 1984), heavy metals (Jones 1975) and diesel oil (Tedengren \& Kautsky 1987). The contrary view was put forward by Gray (1974, 1981), Jernelöv \& Rosenberg (1976) and Rosenberg (1976), proposing that since estuarine species have a wider tolerance to salinity, temperature and oxygen levels, this tolerance will pre-adapt the organisms to tolerate pollution stress. The field evidence for this would be that those species surviving in polluted marine areas are often the same as those found in estuaries. Sensitivity to pollution may thus be related to niche width of the organism (Levins 1968, Fisher 1977).

Using Gammarus duebeni and $G$. oceanicus as model organisms we compare the physiological responses of these species from marine and brackish environments to acute salinity changes and exposure to cadmium and diesel oil. Since $G$. duebeni is more tolerant to fluctuating salinities (Bulnheim 1972, 1979) and has a broader salinity range (Kolding 1985) than other Gammarus spp., we wanted to test if this broadniched species would also be more resistant to pollutants. We also wanted to investigate whether there are any differences in sensitivity between Baltic and North Sea populations of $G$. oceanicus towards acute exposure to diesel oil and cadmium, representing 2 types of toxic substances, and whether the sensitivity of a homoiosmotic species to pollution acts synergistically with a salinity decrease, as in the poikilosmotic Mytilus edulis (Tedengren \& Kautsky 1987). The work described here is concerned with changes in physiological parameters including oxygen uptake, nutrient release, and $\mathrm{O}: \mathrm{N}$ and $\mathrm{O}: \mathrm{P}$ ratios.

\section{MATERIALS AND METHODS}

Experiments were performed at the Askö Laboratory, Sweden, in the northern Baltic proper $\left(58^{\circ} 49^{\prime} \mathrm{N}\right.$, $19^{\circ} 39^{\prime} \mathrm{E}$ ) in June 1986 and at the Tjärmö Marine Biological Laboratory, Sweden, on the North Sea $\left(58^{\circ} 53^{\prime} \mathrm{N}\right.$, $11^{\circ} 09^{\prime} \mathrm{E}$ ) in July and October 1986.

Gammarus oceanicus were obtained from the Fucus belt at a depth of 1 to $3 \mathrm{~m}$ at both localities. Ambient salinities and temperatures at collection sites were $6.5 \% \mathrm{~S}, 8^{\circ} \mathrm{C}$ and $24.0 \% \mathrm{~S}, 14^{\circ} \mathrm{C}$ for the Baltic and North Seas respectively. $G$. duebeni were, in both areas, collected from rock-pools of varying salinities $(0$ to $30 \%$ S). Specimens were kept for $24 \mathrm{~h}$ in aerated aquaria of 6.5 and $24.0 \% \mathrm{~S}$, respectively, at the 2 laboratories in thermoconstant rooms of $10^{\circ} \mathrm{C}$ in order to adapt to the experimental conditions. Their acute responses were measured in 9 experiments for each species, at both localities, with different combinations of salinity and additions of diesel oil and cadmium. From pilot tests in 1985 we determined suitable concentration of pollutants, duration of experiments and salinity ranges.

The following salinities were used. At Askö, 4.0, 6.5 (ambient) and 9.0\% S. At Tjärnö 18.0, 24.0 (ambient) and $30.0 \% \mathrm{~S}$. Low salinity water was prepared by diluting seawater of ambient salinity with deionized water, while high salinity water was prepared by adding commercial iodine-free seawater salt to water of ambient salinity.

In each experiment six 11 aquaria were used: 2 control aquaria and 4 aquaria with Gammarus. Each Gammarus aquarium contained 20 adult specimens 10 males and 10 females. The average weights of $G$. duebeni were 6.7 and $7.1 \mathrm{mg}$ (dry weight) for the Askö and Tjärnö experiments respectively, while the corresponding weights for $G$. oceanicus were 6.9 and $6.7 \mathrm{mg}$. The duration of the experiments was $6 \mathrm{~h}$, which was assumed to be short enough to prevent starvation effects and accumulation effects from excretory products, but, on the other hand, long enough to allow short-term adaptation to experimental conditions.

Cadmium was added from a stock-solution of $\mathrm{CdCl}_{2}$ to obtain the experimental concentration of $1.0 \mathrm{mg} \mathrm{l}^{-1}$. Diesel-oil was emulsified in seawater by vigorous pumping with a syringe and injected into the experimental aquaria. Additions were calculated to result in a concentration of $10 \mathrm{mg} \mathrm{l}^{-1}$ throughout the experiments, but no measurements of the actually resulting hydrocarbon concentrations were made. Although the solubility of many hydrocarbons varies with salinity, these differences are only a few percent at the experimental salinities and temperatures used (Whitehouse 1984). Also, since this study aimed at comparing the acute functional response of organisms from the Baltic and North Seas to the addition of certain amounts of pollutants, we regarded the prevailing differences in solubility or chemical appearance due to salinity as being inherent in the environmental characteristics of the Baltic and North Seas.

The concentrations used may seem high, but, considering the following, we regard them as relevant for this comparative study. First, this was a short-term study, second, chronic concentrations of $\mathrm{Cd}$ amounting to 5.6 and $2.25 \mathrm{Mg} \mathrm{l}^{-1}$, respectively, have been measured in not especially polluted parts of the Kattegat and Baltic Sea (Brügman 1981) and third, ${ }^{96} \mathrm{LC}_{50}$ for the blue $\mathrm{crab}$ Callinectes sapidus exposed to $\mathrm{Cd}$ at $15 \% \mathrm{~S}$ is 4.7 $\mathrm{mg}^{-1}$ (Frank \& Robertson 1979). Regarding normal concentrations of hydrocarbons there is little informa- 
tion, but during an oil spill situation they will certainly reach concentrations well above those used here.

During the experiments, oxygen consumption was measured every hour with a polarographic oxygen electrode (Yellow Springs Instruments 59) modified with a stirring device, thus giving 30 replicate measurements for each treatment. $\mathrm{NH}_{4}-\mathrm{N}$ and $\mathrm{PO}_{4}-\mathrm{P}$ excretion were determined according to Carlberg (1972) and the amphipods were dried at $70^{\circ} \mathrm{C}$ and weighed. O:N and $\mathrm{O}: \mathrm{P}$ ratios were calculated in atomic equivalents. The ratio of oxygen consumed to nitrogen excreted $(\mathrm{O}: \mathrm{N})$, is a measure of the relative balance between carbohydrate and protein substrates in the metabolism and has been used to describe the physiological status and stress level of marine invertebrates (e.g. Bayne \& Scullard 1977, Widdows 1978, Widdows et al. 1981, 1984, Bayne et al. 1985, Tedengren \& Kautsky 1986, 1987).

The physiological response of the amphipods to salinity changes and treatments with diesel oil and cadmium is expressed as a Perturbation Index (PI) (cf. Lindblad et al. 1986, in press). Each measured value for respiration rate and excretion of $\mathrm{NH}_{4}-\mathrm{N}$ and $\mathrm{PO}_{4}-\mathrm{P}$ in the treated specimens is divided by the corresponding value of the control specimens.

To obtain an overall measure of disturbance an Absolute Disturbance Index (ADI) was calculated according to Lindblad et al. (in press) and André et al. (in press). ADI is the absolute distance between the metabolic activities of an undisturbed system and a disturbed point in a multidimensional space where each dimension represents the PI of a measured parameter $(X)$. The ADI value is proportional to the disturbance, and larger values indicate a more disturbed situation. The Absolute Disturbance Index is expressed as:

$$
\mathrm{ADI}=\left(\left(\Sigma[\mathrm{PI}(X)-1]^{2}\right) / n\right)^{0.5}
$$

\section{RESULTS}

Table $1 \mathrm{a}, \mathrm{b}, \mathrm{c}$ gives the respiration and excretion rates and the ratios between oxygen consumption and excretion of nutrients for Baltic and North Sea populations of Gammarus duebeni and G. oceanicus exposed to acute salinity changes, diesel-oil and cadmium treatments. The perturbation indexes (PI) for these data are given in Fig. 1.

Any change from ambient salinity increased metabolic activity as indicated by increased respiration and excretion of nutrients (Table 1a; Fig. 1). There were no significant differences between the effects of raising or lowering of salinity, although raised salinities seemed to have only minor effects on respiration of North Sea amphipods. O:N ratios were lowered with altered salinities, more obviously if salinity was lowered. O:P ratios were generally unaffected by alterations in salinity, but were of different magnitude in different experiments (Table 1a). The metabolism of Gammarus oceanicus was in both areas more affected by salinity changes than that of $G$. duebeni. The $G$. duebeni population from the North Sea was less affected in all PIs as well as ADI compared both to North Sea G. oceanicus and to Baltic Sea G. duebeni (Figs. 1 and 2).

Exposure to diesel oil generally resulted in decreased oxygen consumption and a rise in nutrient excretion, leading to lowered $\mathrm{O}: \mathrm{N}$ and $\mathrm{O}: \mathrm{P}$ ratios (Table $1 \mathrm{~b}$; Fig. 1). The response was higher for Gammarus oceanicus in both areas and was aggravated by simultaneous changes in salinity, both if salinity was lowered and if raised. The PIs (Fig. 1) suggest that this effect is more pronounced if salinity is lowered, and also that it is of a higher magnitude in the Baltic Sea, but these differences could not be shown to be statistically significant. The Gammarus duebeni population at Tjärnö, when exposed to diesel oil, was more resistant in all PIs as well as ADI $(p<0.05)$ (Figs. 1 and 2$)$.

A salinity-dependent decrease in respiration following exposure to cadmium was observed in all populations (Table 1c; Fig. 1). Excretion of nutrients increased, leading to lower O:N and O:P ratios. The response to cadmium was enhanced at low salinities and reduced if salinity was raised, showing that the toxic effect of cadmium is aggravated by low-salinity conditions. Gammarus duebeni was more resistant to cadmium exposure than G. oceanicus, especially in the North Sea populations (Figs. 1 and 2).

\section{DISCUSSION}

\section{Salinity effects}

In our study we observed the lowest respiration rates at ambient salinities. When salinity was lowered respiration increased strongly, while raised salinities increased respiration only to a minor extent, especially in North Sea amphipods. In accordance with this Kinne (1952) found that oxygen consumption of Gammarus duebeni increased in suboptimal salinities $(5 \% \mathrm{~S}-$ fresh water), but contrary to our data he found that respiration decreased in supraoptimal salinities (22 to $30 \%$ S). Suomalainen (1958) measured constant rates of respiration between 1 and $20 \% \mathrm{~S}$ in 4 Gammarus species and McLusky (1969) could not assess significant differences in respiration of the amphipod Corophium volutator between 1 and $30 \%$ S. Dorgelo (1973) obtained variable results with 3 Gammarus species, but the dominating effect of salinity was a 
Table 1 Gammarus spp. Respiration, excretion and atomic O:N and O:P ratios (with SE in parentheses) compared between Baltic Sea and North Sea populations, exposed to (a) acute changes in salinity, (b) treatment with diesel-oil and (c) treatment with cadmium. Mean values per $\mathrm{g}$ dry weight. Duration of adaptation to experimental conditions $24 \mathrm{~h}$, exposure and measurements of metabolism $6 \mathrm{~h}$

\begin{tabular}{|c|c|c|c|c|c|c|c|}
\hline \multirow[t]{2}{*}{ Species } & \multirow[t]{2}{*}{ Location } & \multirow{2}{*}{$\begin{array}{c}\text { Salinity } \\
(\% \mathrm{~S})\end{array}$} & \multirow{2}{*}{$\begin{array}{c}\text { Respiration } \\
\left(\mathrm{mg} \mathrm{O} \mathrm{O}_{2}^{-1} \mathrm{~h}^{-1}\right)\end{array}$} & \multicolumn{2}{|c|}{ Excretion } & \multirow{2}{*}{$\begin{array}{l}\text { O:N ratio } \\
\text { (atomic) }\end{array}$} & \multirow{2}{*}{$\begin{array}{l}\text { O:P ratio } \\
\text { (atomic) }\end{array}$} \\
\hline & & & & $\begin{array}{r}\mathrm{NH}_{4}-\mathrm{N} \\
(\mu \mathrm{g}\end{array}$ & $\begin{array}{r}\mathrm{PO}_{4}-\mathrm{P} \\
-1)\end{array}$ & & \\
\hline \multicolumn{8}{|c|}{ (a) Non-treated gammarids } \\
\hline \multirow{6}{*}{$\begin{array}{l}\text { Gammanus } \\
\text { duebeni }\end{array}$} & Baltic Sea & 4.0 & $1.82(0.05)$ & $49.9(6.8)$ & $18.3(5.7)$ & $31.9(4.8)$ & $192.4(7.3)$ \\
\hline & & $6.5^{\circ}$ & $1.61(0.08)$ & $37.5(5.1)$ & $17.3(3.2)$ & $37.8(3.6)$ & $180.8(11.3)$ \\
\hline & & 9.0 & $1.72(0.03)$ & $45.9(4.1)$ & $17.7(3.1)$ & $32.8(4.3)$ & $188.7(8.7)$ \\
\hline & North Sea & 18.0 & $1.44(0.03)$ & $41.0(3.4)$ & $8.4(1.3)$ & $30.7(2.9)$ & $331.2(9.7)$ \\
\hline & & $24.0^{\circ}$ & $1.38(0.02)$ & $36.4(4.8)$ & $7.3(2.3)$ & $33.2(3.8)$ & $364.8(16.2)$ \\
\hline & & 30.0 & $1.40(0.06)$ & $39.1(3.8)$ & $8.7(1.6)$ & $31.3(1.7)$ & $311.9(11.3)$ \\
\hline \multirow{6}{*}{$\begin{array}{l}\text { Gammarus } \\
\text { oceanicus }\end{array}$} & Baltic Sea & 4.0 & $1.64(0.04)$ & $54.5(7.5)$ & $14.7(0.9)$ & $26.3(7.5)$ & $216.9(8.4)$ \\
\hline & & $6.5^{\circ}$ & $1.47(0.07)$ & $36.2(1.0)$ & $13.2(0.9)$ & $35.5(4.8)$ & $216.4(2.0)$ \\
\hline & & 9.0 & $1.62(0.08)$ & $47.6(1.4)$ & $14.5(1.3)$ & $29.8(2.9)$ & $217.2(2.8)$ \\
\hline & North Sea & 18.0 & $1.70(0.06)$ & $62.8(6.6)$ & $14.7(3.7)$ & $23.7(2.9)$ & $223.6(8.8)$ \\
\hline & & $24.0^{\circ}$ & $1.58(0.02)$ & $38.6(2.5)$ & $12.9(4.2)$ & $35.8(1.6)$ & $237.3(6.2)$ \\
\hline & & 30.0 & $1.59(0.05)$ & $48.9(4.7)$ & $13.3(2.8)$ & $28.4(2.7)$ & $231.6(5.9)$ \\
\hline \multicolumn{8}{|c|}{ (b) Diesel-oil treatment } \\
\hline \multirow{6}{*}{$\begin{array}{l}\text { Gammarus } \\
\text { duebeni }\end{array}$} & Baltic Sea & 4.0 & $1.57(0.09)$ & $49.2(8.3)$ & $20.5(1.7)$ & $27.9(5.6)$ & $148.3(8.1)$ \\
\hline & & $6.5^{\circ}$ & $1.53(0.07)$ & $40.1(2.3)$ & $20.6(7.4)$ & $33.4(2.8)$ & $144.2(5.6)$ \\
\hline & & 9.0 & $1.54(0.08)$ & $47.1(5.3)$ & $19.9(2.0)$ & $28.6(4.3)$ & $150.3(10.7)$ \\
\hline & North Sea & 18.0 & $1.35(0.08)$ & $36.8(0.7)$ & $9.2(1.7)$ & $32.1(3.9)$ & $284.0(8.6)$ \\
\hline & & $24.0^{\circ}$ & $1.32(0.07)$ & $36.3(0.8)$ & $8.5(3.1)$ & $31.8(2.6)$ & $302.1(10.0)$ \\
\hline & & 30.0 & $1.31(0.05)$ & $33.8(2.7)$ & $8.0(1.8)$ & $33.9(2.1)$ & $316.4(13.7)$ \\
\hline \multirow{6}{*}{$\begin{array}{l}\text { Gammarus } \\
\text { oceanicus }\end{array}$} & Baltic Sea & 4.0 & $1.29(0.20)$ & $61.5(1.6)$ & $19.0(0.5)$ & $18.4(3.4)$ & $131.4(10.1)$ \\
\hline & & $6.5^{\circ}$ & $1.34(0.04)$ & $49.5(3.6)$ & $18.4(0.9)$ & $23.7(3.6)$ & $141.3(4.6)$ \\
\hline & & 9.0 & $1.31(0.04)$ & $58.6(2.5)$ & $18.9(2.7)$ & $19.5(2.5)$ & $134.6(5.2)$ \\
\hline & North Sea & 18.0 & $1.32(0.05)$ & $58.5(4.8)$ & $12.1(2.7)$ & $19.8(3.7)$ & $211.7(9.2)$ \\
\hline & & $24.0^{\circ}$ & $1.41(0.03)$ & $39.5(3.4)$ & $12.6(1.7)$ & $31.3(5.8)$ & $216.1(11.6)$ \\
\hline & & 30.0 & $1.44(0.04)$ & $42.1(2.2)$ & $13.4(2.1)$ & $29.9(2.8)$ & $208.6(7.0)$ \\
\hline \multicolumn{8}{|c|}{ (c) Cadmium treatment } \\
\hline \multirow{6}{*}{$\begin{array}{l}\text { Gammarus } \\
\text { duebeni }\end{array}$} & Baltic Sea & 4.0 & $1.35(0.10)$ & $59.7(9.1)$ & $20.5(5.5)$ & $19.8(3.3)$ & $127.9(11.6)$ \\
\hline & & $6.5^{\circ}$ & $1.47(0.09)$ & $50.2(4.1)$ & $19.2(3.3)$ & $25.6(4.8)$ & $148.5(10.3)$ \\
\hline & & 9.0 & $1.50(0.06)$ & $46.4(8.1)$ & $19.2(5.1)$ & $28.3(5.7)$ & $151.6(12.6)$ \\
\hline & North Sea & 18.0 & $1.22(0.06)$ & $39.6(5.2)$ & $7.9(1.6)$ & $27.0(2.7)$ & $298.1(23.2)$ \\
\hline & & $24.0^{\circ}$ & $1.27(0.05)$ & $37.9(2.3)$ & $9.3(1.0)$ & $29.4(1.6)$ & $264.7(17.4)$ \\
\hline & & 30.0 & $1.36(0.04)$ & $31.8(4.1)$ & $6.4(2.2)$ & $37.4(1.9)$ & $411.0(19.8)$ \\
\hline \multirow{6}{*}{$\begin{array}{l}\text { Gammarus } \\
\text { oceanicus }\end{array}$} & Baltic Sea & 4.0 & $1.10(0.17)$ & $56.5(1.5)$ & $17.4(1.1)$ & $17.0(1.7)$ & $122.3(6.4)$ \\
\hline & & $6.5^{\circ}$ & $1.15(0.13)$ & $42.5(4.1)$ & $15.5(1.0)$ & $23.7(2.2)$ & $144.2(5.3)$ \\
\hline & & 9.0 & $1.39(0.03)$ & $46.1(4.6)$ & $17.7(1.6)$ & $26.4(2.3)$ & $151.8(6.2)$ \\
\hline & North Sea & 18.0 & $1.01(0.09)$ & $57.4(3.2)$ & $13.0(2.4)$ & $15.4(3.4)$ & $150.2(4.9)$ \\
\hline & & $24.0^{\circ}$ & $1.38(0.08)$ & $44.4(2.9)$ & $16.5(2.3)$ & $27.2(2.0)$ & $161.8(12.4)$ \\
\hline & & 30.0 & $1.51(0.04)$ & $40.2(4.1)$ & $19.7(4.7)$ & $32.9(3.3)$ & $148.3(7.3)$ \\
\hline
\end{tabular}

decrease in oxygen consumption with increasing salinity $(0$ to $36 \%$ S).

Increased locomotor activity during the initial period of salinity stress may raise respiration. This period will, however, last only about 1 to $5 \mathrm{~h}$ after which a new level of routine $\mathrm{O}_{2}$ demand is reached and maintained for 30 to $40 \mathrm{~h}$ (Bulnheim 1972). Since our specimens had been acclimated to experimental salinities over $24 \mathrm{~h}$ prior to start of the experiment they would have been in the phase of routine $\mathrm{O}_{2}$ demand.

When euryhaline crustaceans adapt to environmental salinity variations, significant changes in ammonia excretion are observed. Decreasing salinity generally raises ammonia excretion and vice versa 
RESPIRATION


O:N RATIO


Fig. 1. Gammarus spp. Perturbation indexes (PI) for respiration and O:N ratios compared between Baltic Sea and North Sea populations exposed to acute changes in salinity and treatments with diesel oil and cadmium. Mean value of control (non-treated specimens at ambient salinity) is set to 1 indicated by the line. SE of means are shown

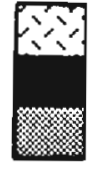

Non-treated Gammarus

Diesel-oil treatment

Cadmium exposure 

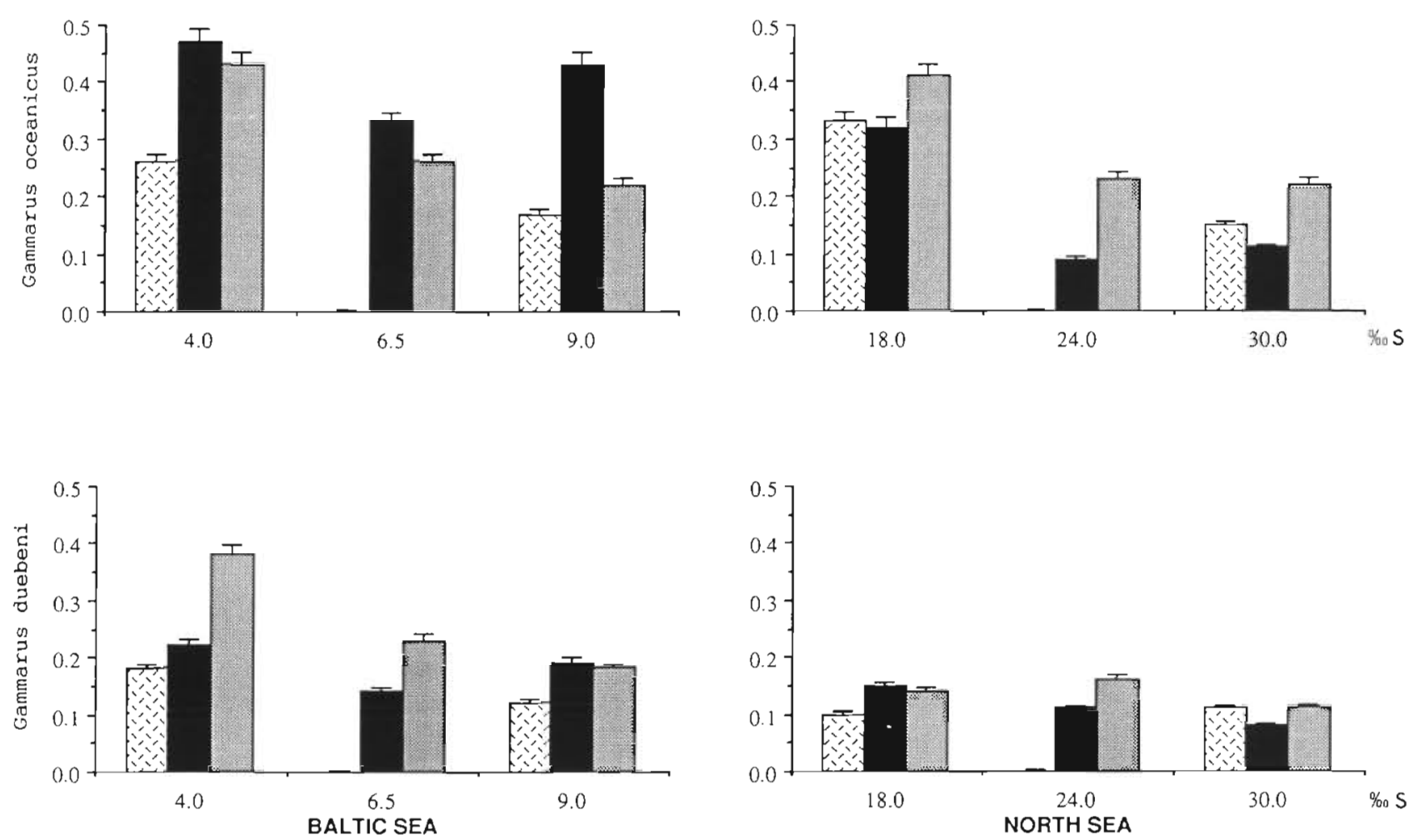

Fig. 2. Gammarus spp. Absolute disturbance index (ADI) calculated from perturbation indexes for all measured physiological parameters. Disturbance of control (non-treated specimens at ambient salinity) is zero. Legend as Fig. 1

(Spaargaren 1982, 1985, Regnault 1984). In our experiments, any deviation from ambient salinity caused increased $\mathrm{NH}_{4}$ excretion, indicating higher metabolic activity and increased osmoregulatory work. As indicated by the perturbation index for O:N ratios (Fig. 1), this effect was more pronounced when salinity was reduced than when it was raised. This is probably due to $\mathrm{NH}_{4}-\mathrm{N}$ being used as counter-ion in the mechanisms of active uptake of $\mathrm{Na}^{+}$and $\mathrm{K}^{+}$, and by partly replacing losses of these ions through urine in diluted media (Spaargaren 1982, Gilles \& Pequeux 1983).

Gammarus species are capable of hyperosmotic regulation at low salinities ( $G$. duebeni up to $23 \%$ i Kinne 1971), but become osmoconformers at higher salinities. G. duebeni exhibits especially strong osmoregulatory abilities (Bulnheim 1972,1979), as also indicated in our study by the PIs of $G$. duebeni, for both respiration and $\mathrm{O}: \mathrm{N}$ ratios, being closer to control values than those of G. oceanicus (Fig. 1). In these homoiosmotic amphipods respiration and $O: N$ ratios were highest at ambient salinities, indicating that energy expenditures for osmoregulatory work will increase with any change in salinity. However, the reduction of this index was generally more pronounced if salinity was lowered. In the poikilosmotic mussel Mytilus edulis, Tedengren \& Kautsky (1986) found that O:N ratios decreased if salinities were lowered, but always increased with raised salinities. This was assumed to indicate a generally less favourable energy balance only at lower salinities, resulting in the lower growth rates and smaller maximum sizes observed in $M$. edulis from the Baltic Sea (Kautsky 1981, 1982).

\section{Diesel-oil treatment}

The effects of oil on various physiological functions of marine invertebrates are assumed to be concentrationdependent (Edwards 1978, Laughlin \& Neff 1981). At low concentration, hydrocarbons exert effects predominantly through their action as narcotics (Crisp et al. 1967), which would affect oxygen consumption indirectly by decreasing locomotor activity. Narcosis would be expected to be a major effect mainly at low concentrations, or early in the course of exposure, when oil concentrations in the tissue are still relatively low. Ponat (1975) showed that oxygen consumption was reduced to $40 \%$ in Gammarus salinus at $15 \%$ S and $15^{\circ} \mathrm{C}$ owing to the narcotic influence of crude oil.

Higher oil concentrations have been shown to increase respiration rates in isolated mitochondria from amphipods (Percy 1977). This was explained in terms of enhancement of some aspect of electron transport through effects on mitochondrial membranes. Larval lobsters exposed to sublethal concentrations of crude oil ( $0.25 \mathrm{mg} \mathrm{l}^{-1}$ for $4 \mathrm{~d}$ ) exhibited significant reductions in respiration rates and $\mathrm{O}: \mathrm{N}$ ratios (Cappuzzo \& Lancaster 1981). The reduction in $O: N$ ratios was explained 
by an increased dependence on protein catabolism for immediate energy needs as a result of the oil exposure.

Lindén (1976) observed behavioural disturbances when Gammarus oceanicus was exposed to oil ( 5 to 20 $\mathrm{mg} \mathrm{l}^{-1}$ ). The first symptoms were a continuous and hectic swimming, probably an avoidance reaction; later the amphipods stopped swimming and began to crawl on the bottom. This might be explained by the above-mentioned narcotic effect, or by surfaces and fine structures, such as receptor cells and external glandular tissues, becoming clogged and their efficiency reduced. Carr \& Lindén (1984) also observed decreased $O: N$ ratios for $G$. salinus exposed to oil as well as oil/dispersant.

In the present study, we could not detect any signs of impaired swimming or other effects of a physical or mechanical nature. The amphipods exhibited decreased respiration rates and generally showed reduced $O: N$ ratios when exposed to an acute oilspill. We interpret the decreased $\mathrm{O}: \mathrm{N}$ ratios in our experiments as indicators of increased protein catabolism. The effects were more pronounced in combinations with changed salinity $(p<0.05)$, especially if the salinity was lowered. In the poikilosmotic Mytilus edulis acute oil exposure also resulted in reduced $O: N$ ratios, but it was found that lowered salinity and diesel oil acted synergistically to a higher degree in Baltic $(p<0.001)$ than in North Sea mussels $(p<0.1)$ (Tedengren \& Kautsky 1987). In the present study of homoisosmotic gammarids no synergistic effects, but only additive effects, could be detected in the experiments with diesel oil and changed salinities. Nevertheless, we assume that diesel oil may have direct effects on the osmoregulatory activity of Gammarus spp. As indicated by lower ADIs (Fig. 2), G. duebeni was less sensitive to oil exposure than $G$. oceanicus $(p<0.001)$.

\section{Cadmium treatment}

Cadmium exposure also reduced respiration and increased excretion of $\mathrm{NH}_{4}-\mathrm{N}$ and $\mathrm{PO}_{4}-\mathrm{P}$, leading to lowered O:N and O:P ratios. These effects were found to be strongly salinity-dependent with the PIs more deviant from control, and the highest ADIs obtained, at the lowest salinities $(p<0.001)$. The salinity-dependent toxicity of cadmium and several other heavy metals is well known (Theede et al. 1979, Fischer 1986, review in McLusky et al. 1986) and has been assumed to be due mainly to the formation of less toxic complexes with chloride-, hydroxy- and carbonate-ions in more saline regimes (Olson \& Harrel 1973, Jones 1975, Jackim et al. 1977. Phillips 1977, Bryant et al. 1984, 1985). George et al. (1977), Bouquegneau \& Gilles (1979) and Phillips (1980) also suggested direct salinity effects on metal uptake processes involving competition between cadmium and calcium/magnesium as cations at uptake sites, which would thus affect osmoregulation. This would lead to relatively lower toxicity at high salinities both through reduction of free $\mathrm{Cd}$ ions and through lower rates of bioaccumulation. Sublethal effects of cadmium in crustaceans have been shown to interfere with osmoregulation, oxygen consumption, gill structure, moulting, limb regeneration and larval development (Phillips 1980), and cadmium was found to cause osmotic elevation in crab serum and to reduce the rate of oxygen consumption in Carcinus maenas and $C$. irroratus (Thurberg et al. 1973).

The absolute disturbance index (ADI) showed that Gammarus duebeni is less sensitive to additions of cadmium than G. oceanicus, especially in the North Sea population $(p<0.001)$ (Fig. 2). However, a comparison between the $G$. oceanicus populations from the Baltic and North Seas provided no significant differences in response to cadmium treatment. We suggest that $1 \mathrm{mg} \mathrm{l}^{-1}$ cadmium may have been too toxic to reveal any differences in sublethal physiological response, as such effects may be observed at as low as 1 and $7 \mu \mathrm{g} \mathrm{l}^{-1}$ in fresh and marine waters, respectively (Taylor 1981).

\section{Comparison of stress responses between Baltic and North Sea populations}

In both areas, the stress sensitivity expressed as the perturbation index (PI) of respiration and $\mathrm{O}: \mathrm{N}$ ratio (Fig. 1), as well as the absolute disturbance index (ADI) (Fig. 2), were significantly $(p<0.001)$ higher in Gammarus oceanicus than in $G$. duebeni following exposure to acute salinity changes and/or treatments with diesel-oil or cadmium.

We believe that the higher tolerance of Gammarus duebeni is coupled to this species having evolved in, and being adapted to, physically more variable environments. G. duebeni is more euryhaline, and has the lowest oxygen demand of gammarids studied (Bulnheim 1979). This reduces metabolic energy expenditures and is considered of adaptive significance to the harsh conditions of the upper shore environment. As shown by Bulnheim (1972), $G$. duebeni also exhibits the highest developed capabilities for compensatory adjustments to rapid salinity changes, which leads to less extensive alterations in respiratory rates and to faster adaptation following osmotic stress than in other gammarids.

Fisher (1977) suggested that organisms which have evolved in and adapted to physically variable environments would, because of their adaptations, be better able to tolerate any toxic compound (and possibly 
every perturbation) than would morphologically similar organisms adapted to stable environments. This ability involves the evolution of a tolerance of the effects produced by other toxic substances, which may confer upon a cell resistance to exotic chemicals producing similar effects. Essentially, these are also the lines along which Gray (1974), Jernelov \& Rosenberg (1976) and Rosenberg (1976) argue. Our data suggest this to be true for related broad-and narrow-niched species, but it does not seem to be valid when the sensitivity of the same species in 2 areas of different background stress is compared.

Exposure to diesel oil in combination with changes in salinity exerts more pronounced effects in the Baltic population of Gammarus oceanicus than in the North Sea population. G. duebeni in the North Sea also exhibits a higher degree of resistance to both cadmium and diesel-oil exposure than in the Baltic Sea $(p<0.01 j$, whereas the ability to withstand filuctuations in salinity is about the same in both areas.

Previous studies on the euryhaline and poikilosmotic blue mussel Mytilus edulis by Tedengren \& Kautsky (1987) also showed that physiological stress, as indicated by decreasing $\mathrm{O}: \mathrm{N}$ ratios, is aggravated by lowering of salinity and that Baltic mussels were more sensitive than North Sea mussels to additional stress (diesel-oil) superimposed on the already existing salinity stress.

The generally more pronounced effect of cadmium or diesel-oil on the Baltic populations can be explained by differences in salinity, through a number of mechanisms. Our clata indicate that poisonous substances may interact with membrane permeability and osmoregulatory mechanisms, which are in any case generally more activated in low-saline areas. Furthermore, organisms from low salinity areas will generally be relatively more exposed to substances in the water as they will generally process more water due to osmoregulation and will thus pass a relatively larger amount of a specific substance through their bodies, which then can accumulate and/or exert effects. This is enhanced by the lower $\mathrm{Ca}^{2+}$ concentration in the Baltic Sea, which will increase the permeability of cell membranes (Schlieper 1971), and increase toxicity. Furthermore, the relative ionic concentration of a given amount of poisonous substance in the low salinity Baltic Sea will be higher than in the North Sea. Finally, the characteristics of the poisonous substance may change with salinity, and generally lead to increased toxicity with lowered salinities. This is definitely valid for cadmium and most other heavy metals, while it is of minor importance for petroleum hydrocarbons.

Acknowledgements. We thank the Directors of the Askö Laboratory and of Tjärnö Marine Biological Laboratory for providing working facilities. The work was partly financed by grants from the Helge Ax:son Johnson and Lars Hiertas minne foundations.

\section{LITERATURE CITED}

André, C., Kautsky, N., Kautsky, U., Lindblad, C., Tedengren $M$. (in press). In situ measurements of the functional response of benthic suspension feeders exposed to cadmium and anti-fouling paint. Kieler Meeresforsch.

Bayne, B. L., Scullard, C. (1977). Rates of nitrogen excretion by species of Mytilus (Bivalvia: Mollusca). J. mar biol. Ass. U. K. $57: 355-369$

Bayne, B. L., Brown, D. A., Burns, K., Dixon, D. R., Ivanovici, A., Livingstone, D. R., Lowe, D. M., Moore, M. N., Stebbing, A. R. D., Widdows, J. (1985). The effects of stress and pollution on marine animals. Preager publishers CBS Educational and Professional Publishing, New York

Bouquegneau, J. M., Gilles, R. (1979). Osmoregulation and pollution of the aquatic medium. In: Gilles, R. (ed.) Mechanisms of osmoregulation in animals. Wiley, Chichester, p. 56:3-580

Brügman, L. (1981). Heavy metals in the Baltic Sea. Mar. Pollut. Bull. 12 (6): 214-218

Bryant, V., McLusky, D. S., Roddie, K., Newsbery, D. M. (1984). Effect of temperature and salinity on the toxicity of chromium on three estuarine invertebrates (Corophium volutator, Macoma balthica, Nereis diversicolor). Mar. Ecol. Prog. Ser. 20: 137-149

Bryant, V., Newsbery, D. M., Mclusky, D. S., Cambell, R (1985). Effect of temperature and salinity on the toxicity of nickel and zinc on two estuarine invertebrates (Corophium volutator, Macoma balthica). Mar. Ecol. Prog. Ser. 24: $139-153$

Bulnheim, H.-P. (1972). Vergleichende Untersuchungen zur Atmungsphysiologie euryhaliner Gammariden unter besonderer Berücksichtigung der Salzgehaltsanpassung. Helgoländer wiss. Meeresunters. 23: 485-534

Bulnheim, H.-P. (1979). Comparative Studies on the physiological ecology of five euryhaline Gammarus species. Oecología 44: 80-86

Bulnheim, H.-P., Scholl, A. (1981). Genetic variation between geographic populations of the amphipods Gammarus zaddachi and G. salinus. Mar Biol. 64: 105-115

Capuzzo, J. M., Lancaster, B. A. (1981). Physiological effects of South Louisiana crude oil on larvae of the American lobster (Homarus americanus). In: Vernberg. F. J.. Calabrese, A., Thurberg, F. P., Vernberg, W B. leds.) Biological monitoring of marine pollutants. Academic Press, New York, p. 405-423

Carlberg, S. (ed.) (1972) New Baltic Manual. ICES Cooperative Res. Rep. Ser. A, No. 29

Carr, R. S., Lindén, O. (1984). Bioenergetic responses of Gammarus salinus and Mytilus edulis to oil dispersants in a model ecosystem. Mar Ecol. Prog. Ser. 19: 285-291

Crisp, D. J., Christie, A. O., Ghobashy. A. F. A. (1967). Narcotic and toxic action of organic compounds on barnacle larvae. Comp. Biochem. Physiol. 22: 629-649

Dorgelo, J. (1973). Comparative ecophysiology of Gammarids (Crustacea: Amphipoda) from marine, brackish and freshwater habitats exposed to the influence of salinity-temperature combinations. III. Oxygen uptake. Netherl. J. Sea Res. 7: 253-266

Edwards, R. R. C. (1978). Effects of water-soluble oll fractions on metabolism growth and carbon budget of the shrimp Crangon crangon. Mar Biol. 46: 259-265 
Fenchel, T M., Kolding, S. (1979). Habitat selection and distribution patterns of five species of the genus Gammarus. Oikos 33: 316-322

Fischer, H. (1986). Influence of temperature, salinity, and oxygen on the cadmium balance of mussels Mytilus edulis. Mar Ecol. Prog. Ser 32: 265-278

Fisher, N. S. (1977). On the differential sensitivity of estuarine and open-ocean diatoms to exotic chemical stress. Am. Nat. Vol. III No. 981

Frank, P. M., Robertson, P. B. (1979). The influence of salinity on toxicity of cadmium and chromium to the blue crab, Callinectes sapidus. Bull. environ. Contam. Toxicol. 21: 74-78

George, S. G., Carpene, E., Coombs, T L. (1977). The effect of salinity on the uptake of cadmium by the common mussel, Mytilus edulis (L.). In: McLusky, D. S., Berry, A. J. (eds.) Proc. 12th Europ. Mar. Biol. Symp. Pergamon Press, Oxford p. 189-195

Gilles, R., Pequeux, A. (1983). 4. Interactions of chemical and osmotic regulation with the environment. In: Bliss, D. E. (ed in chief) The biology of Crustacea, Vol. 8; Vernberg, F. J., Vernberg, W B. (eds.) Environmental adaptations. Academic Press, New York, p. 109-177

Gray, J. S. (1974). Synergistic effects of three heavy metals on growth rates of a marine ciliate protozoan. In: Vernberg, W., Vernberg, F. (eds.) Pollution and physiology of marine organisms. Academic Press, New York, p. 465-485

Gray, J. S. (1981). The ecology of marine sediments. Cambridge University Press, Cambridge

Jackim, E., Morrison, G., Steele, R. (1977). Effects of environmental factors on radiocadmium uptake by four species of marine bivalves. Mar. Biol. 40: 303-308

Jernelöv, A., Rosenberg, R. (1976). Stress tolerance of ecosystems. Environ. Conserv. 3 (1): 43-46

Jones, M. B. (1975). Synergistic effects of salinity, temperature and heavy metals on mortality and osmoregulation in marine and estuarine isopods (Crustacea). Mar. Biol. 30: $13-20$

Kautsky, N. (1981). On the trophic role of the blue mussel (Mytilus edulis L.) in a Baltic coastal ecosystem and the fate of the organic matter produced by the mussels. Kieler Meeresforsch. Sonderh. 5: 454-461

Kautsky, N. (1982). Growth and size structure in a Baltic Mytilus edulis population. Mar Biol. 68: 117-133

Kinne, O. (1952). Zur Biologie und Physiologie von Gammarus duebeni Lillj. V. Untersuchungen über Blutkonzentration, Herzfrequenz und Atmung. Kieler Meeresforsch. 9: $134-150$

Kinne, O. (1959). Ecological data on the amphipod Gammarus duebeni. A monograph. Veröff. Inst. Meeresforsch. Bremerhaven VI: $177-202$

Kinne, O. (1964). The effects of temperature and salinity on marine and brackish water animals. II. Salinity and temperature. Salinity combinations. Oceanogr mar. Biol. A. Rev. 2: 281-339

Kinne, O. (1971). In: Kinne, O. (ed.) Marine ecology. Vol. I. Environmental factors, Part 2. Wiley, London, p. 821-995

Kolding, S. (1981). Habitat selection and life cycle characteristics of five species of the amphipod genus Gammarus in the Baltic. Oikos 37: 173-178

Kolding, S. (1985). Genetic adaptation to local habitats and speciation processes within the genus Gammarus (Amphipoda: Crustacea). Mar. Biol. 89: 249-255

Kolding, S. (1986). Interspecific competition for mates and habitat selection in five species of Gammarus (Amphipoda: Crustacea). Mar. Biol. 91: 491-495
Kolding, S., Fenchel, T M. (1979). Coexistence and life cycle characteristics of five species of the amphipod genus Gammarus. Oikos 33: 323-327

Kolding, S., Fenchel, T M. (1981). Patterns of reproduction in different populations of five species of the amphipod genus Gammarus. Oikos 37: 167-172

Landner, L. et al. (1982). Systems for testing and hazard evaluation of chemicals in the aquatic environment. Report No. 1 National Swedish Environmental Protection Board, Solna. SNV PM 1631: 1-81

Laughlin, R. B., Neff, J. M. (1981). Ontogeny of respiratory and growth responses of larval mud crabs Rhithropanopeus harrisii exposed to different temperatures, salinities and naphtalene concentrations. Mar. Ecol. Prog. Ser 5: 319-332

Levins, R. (1968). Evolution in changing environments. Princeton Univ. Press, Princeton, New Jersey

Lindblad, C., Kautsky, N., Kautsky, U. (1986). An in situ method for bioassay studies of functional response of littoral communities to pollutants. Ophelia 4 (Suppl.): $159-165$

Lindblad, C., Kautsky, U., Kautsky, N. (in press). A in situ system for evaluating effects of toxicants on the metabolism of littoral communities. In: Cairns, J. Jr, Pratt, J. R. (eds.) Functional testing of aquatic biota for estimating hazards of chemicals. American society for testing and materials. Philadelphia 1988, ASTM, STP 988

Lindén. O. (1976). Effects of oil on the amphipod Gammarus oceanicus. Environ. Pollut. 10: 239-250

Mclusky, D. S. (1969). The oxygen consumption of Corophium volutator in relation to salinity. Comp. Biochem. Physiol. 29: 743-753

McLusky, D. S., Bryant, V., Campbell, R. (1986). The effects of temperature and salinity on the toxicity of heavy metals to marine and estuarine invertebrates. Oceanogr. mar Biol. A. Rev. 24: 481-520

Olson, K. R., Harrel, R. C. (1973). Effects of salinity on acute toxicity mercury, copper and chromium for Rangia cuneata (Pelecypoda, Matridae). Contr. mar. Sci. 17: 9-13

Percy, J. A. (1977). Effects of dispersed crude oil upon the respiratory metabolism of an arctic marine amphipod, Onisimus (Bolkisimus) affinis. In: Wolfe, D. A. (ed.) Fate and effects of petroleum hydrocarbons in marine organisms and ecosystems. Pergamon Press, New York, p. $192-200$

Phillips, D. J. H. (1977). Effects of salinity on the net uptake of zink by the common mussel Mytilus edulis. Mar. Biol. 41 . $79-88$

Phillips, D. J. H. (1980). Toxicity and accumulation of cadmium in marine and estuarine biotas. In: Nriagu, J. (ed.) Cadmium 1 Chapter 12: 426-569

Ponat, A. (1975). Untersuchungen über den Einfluß von Rohöl auf Überlebensfähigkeit und Sauerstoffverbrauch von Idotea baltica und Gammarus salinus. Kieler Meeresforsch. 31: 26-33

Regnault, M. (1984). Salinity-induced changes in ammonia excretion rate of shrimp Crangon crangon over a winter tidal cycle. Mar. Ecol. Prog. Ser. 20: 119-125

Rosenberg, R. (1976). The relation of treatment and ecological effects in brackish water regions. Pure appl. Chem. 45: 199-203

Schlieper, C. (1971). Physiology of brackish water. In: Remane, A., Schlieper, C. (eds.) Biology of brackish water. John Wiley and Sons, New York, p. 211-350

Spaargaren, D. H. (1982). The ammonium excretion of the shore crab, Carcinus maenas, in relation to environmental osmotic conditions. Netherl. J. Sea Res. 15 (62): 273-283 
Spaargaren, D. H. (1985). The significance of nitrate in the nitrogenous excretion of Carcinus maenas. Netherl. J. Sea Res. 19 (2): 119-124

Suomalainen, P. (1958). Der Sauerstoffverbrauch einiger finnischer Gammarus-Arten. Verh. int. Verein. theor angew. Limnol. 13: 873-878

Sutcliffe, D. W (1984). Quantitative aspects of oxygen uptake by Gammarus (Crustacea, Amphipoda): a critical review. Freshwater Biology 14: 443-489

Taylor, D. (1981). A summary of the data on the toxicity of various heavy metals to aquatic life. Cadmium, ICI, Brixham, Devon, $16 \mathrm{pp}$.

Tedengren, M. Kautsky, N. (1986). Comparative study of the physiology and its probable effect on size in blue mussels (Mytilus edulis L.) from the North Sea and the northern Baltic proper Ophelia 25 (3): 147-155

Tedengren, M., Kautsky, N. (1987). Comparative stress response to diesel oil and salinity changes of Mytilus edulis from the North and Baltic Seas. Ophelia 28 (1): 1-9

Theede, H. (1980). Physiological responses of estuarine animals to cadmium pollution. Helgoländer Meeresunters. 33: 26-35

Theede, $H$. (1984). Physiological approaches to environ-
Inental problems of the Baltic. Limnologica (Berl.) 15 (2): $443-458$

Theede, H., Scholz, N. Fischer, H. (1979). Temperature and salinity effects on the acute toxicity of cadmium to Laomedea loveni (Hydrozoa). Mar Ecol. Prog. Ser. 1. 13-19

Thurberg, F. P., Dawson, M. A., Collier, R. S. (1973). Effects of copper and cadmium on osmoregulation and oxygen consumption in two species of estuarine crabs. Mar. Biol. 23: $171-175$

Whitehouse, B. G. (1984). The effects of temperature and salinity on the aqueous solubility of polynuclear aromatic hydrocarbons. Mar. Chem. 14: 319-332

Widdows, J. (1978). Physiological indices of stress in Mytilus edulis. J. mar. biol. Ass. U. K. 58: 125-142

Widdows, J., Phelps, D. K., Galloway, W. (1981). Measurement of physiological condition of mussels transplanted along a pollution gradient in Narraganset Bay. Mar environ. Res. 4: 181-194

Widdows, J., Donkin, P., Salkeld, P. N., Cleary, J. J., Lowe, D. M., Evans, S. V., Thomson, P. E. (1984). Relative importance of environmental factors in determining physiological differences between two populations of mussels (Mytilus edulis). Mar. Ecol. Prog. Ser. 17 33-47

This article was submitted to the editor; it was accepted for printing on May 13, 1988 